\title{
Personality pattern and emotional stress in the genesis of gastric ulcer ${ }^{1}$
}

\author{
M. H. ALP, J. H. COURT, AND A. KERR GRANT
}

From the Gastroenterology Unit, The Queen Elizabeth Hospital, Woodville, South Australia, and the Department of Mental Health, The University of Adelaide, Adelaide

SUMMARY In a group of 181 persons with a past history of chronic gastric ulcer, a greatly increased incidence of domestic and financial stress has been found, when compared with ageand sex-matched persons with no previous history of gastric ulcer. The consumption of aspirin, alcohol, and cigarettes was also significantly increased. Persons with chronic gastric ulcer were characterized by a personality pattern of independence and self sufficiency, and they are prone to anxiety and depression. This pattern was three times as common as in matched individuals without chronic gastric ulcer.

It is possible that internal conflict between a genetic and an environmentally induced sex role, together with an inability to externalize aggression, may be significant factors in the causation of chronic gastric ulcer.

In 1859 , William Brinton suggested that privation, fatigue, and mental anxiety frequently coincided with the presence of gastric ulceration. Davies and Wilson (1937) found a significant correlation between the onset of symptoms of peptic ulcer and domestic upset, financial stress, or a long past history of 'tension'. Jones (1957) found that anxiety, frustration, resentment, and fatigue were important aggravating factors in the symptomatology of peptic ulceration. Alexander (1950) and Højer-Pedersen (1958) suggested that a psychological disturbance or emotional conflict might be transformed into an organic disease, eg, peptic ulcer.

We have recently completed a retrospective survey of 638 patients presenting with chronic gastric ulceration to two major public hospitals in South Australia between the years 1954 and 1963 (Alp and Grant, 1970). Emotional stresses which were present at the time of admission were documented. At the time of follow up, an assessment was made of the patient's basic personality. The results of this investigation suggest that an

Received for publication 8 January 1970.

${ }^{1}$ Address requests for reprints to Dr A. Kerr Grant, Gastroenterology Unit, The Queen Elizabeth Hospital, Woodville, South Australia. identifiable personality pattern exists in patients with gastric ulcers and that emotional stress may play a part in the genesis of gastric ulcer.

\section{Patients and Methods}

\section{GROUP 1}

The case notes of 638 patients with proven gastric ulcer admitted to the Queen Elizabeth Hospital and the Royal Adelaide Hospital during the years 1954 to 1963 were studied. Criteria for acceptance have been described (Alp and Grant, 1970). Patients were circularized with questionnaires. Alcohol, aspirin, and cigarette consumption, together with domestic, financial, and other stress existing at the time of the patients' admission to hospital, were assessed from the inpatient notes or from completed questionnaires. The questionnaire also included a neuroticism scale questionnaire (NSQ), a series of questions devised by Scheier and Cattell (1961). Of the 247 patients known to be still living, 181 completed the personality assessment. 
GROUP 2

One hundred and eighty-one persons, age- and sexmatched with patients from group 1 and without any previous history of gastric ulceration, were selected at random from hospital domestic staff, outpatients, and visitors, building workers, and members of senior citizens' clubs. Assessment of aspirin and alcohol ingestion, cigarette smoking, and of domestic and financial stress in these persons was graded in a similar fashion to group 1 patients.

Results from these two groups were correlated with an IBM 83 card sorter or CDC 340 computer.

\section{THE QUESTIONNAIRE}

The neuroticism scale questionnaire has been constructed to serve as a screening tool in the identification of emotional disturbances. Four separate factors of the patient's personality can be measured by answers supplied to 40 questions (10 questions for each factor). These factors are estimated in a bipolar fashion.

\section{Factor I}

Tough-mindedness versus tender-mindedness. The tender-minded pole is commonly associated with dependence. The tough-minded pole reflects a tough or harsh background and produces an independent, self-sufficient type of person. This person tends to be more masculine.

\section{Factor $F$}

Cheerfulness versus depression, or happy-golucky versus serious minded.

\begin{tabular}{|c|c|c|c|c|}
\hline & $\begin{array}{l}\text { Factor I } \\
\text { (Tough- } \\
\text { tenderminded) }\end{array}$ & $\begin{array}{l}\text { Factor } F \\
\text { (Cheerful- } \\
\text { depressed) }\end{array}$ & $\begin{array}{l}\text { Factor E } \\
\text { (Dominant- } \\
\text { submissive) }\end{array}$ & $\begin{array}{c}\text { Factor An } \\
\text { (Low-high } \\
\text { anxiety) }\end{array}$ \\
\hline $\begin{array}{l}\text { Mean } \\
\text { SD } \\
\text { 'Normal' population }\end{array}$ & $\begin{array}{l}8 \cdot 7 \\
2 \cdot 96 \\
10 \cdot 4\end{array}$ & $\begin{array}{l}11 \cdot 6 \\
2 \cdot 72 \\
9 \cdot 6\end{array}$ & $\begin{array}{c}14 \cdot 3 \\
3 \cdot 18 \\
11 \cdot 9\end{array}$ & $\begin{array}{l}12 \cdot 6 \\
3.99 \\
9 \cdot 8\end{array}$ \\
\hline
\end{tabular}

Table I Mean scores for patients with gastric ulcer compared with normal population distribution

\begin{tabular}{llllc}
\hline Factor & $\begin{array}{l}\text { Low } \\
\text { Scores }\end{array}$ & Average & $\begin{array}{l}\text { High } \\
\text { Scores }\end{array}$ \\
\hline I $\quad$ (tough- tenderminded) & $46 \cdot 4$ & $29 \cdot 3$ & $8 \cdot 3$ \\
F (cheerful-depressed) & $20 \cdot 0$ & $25 \cdot 3$ & $54 \cdot 7$ \\
E (dominant-submissive) & $17 \cdot 1$ & $29 \cdot 5$ & $53 \cdot 0$ \\
An (low-high anxiety) & $16 \cdot 6$ & $17 \cdot 6$ & $65 \cdot 8$ \\
Expected frequencies & & $31 \cdot 0$ & $38 \cdot 0$ & $31 \cdot 0$ \\
\hline
\end{tabular}

Table II Percentage frequencies of scores on each factor of the neuroticism scale questionnaire in 181 patients with gastric ulcer compared with the expected frequency for the normal population

${ }^{1}$ From Scheier and Cattell (1961).

\section{Factor E}

Dominance versus submissiveness. This factor is strongly determined by heredity. The submissive pole is associated with femininity and an inability to express aggressive feelings outwardly.

\section{Factor $A n$}

Low versus high anxiety. Men and women score similarly on this factor. It is high in physical or emotional illness.

\section{Results}

Of the 181 patients in group 1 who completed the NSQ, domestic stress was noted by 54 patients $(30 \%)$. Financial stress was present in 90 patients $(50 \%)$. Eighty-eight patients $(48 \%)$ ingested aspirin daily, 70 (39\%) drank alcohol daily, and $122(67 \%)$ smoked cigarettes daily. In group 2 , five people $(3 \%)$ had domestic stress, $20(11 \%)$ had financial stress, $22(12 \%)$ ingested aspirin daily, $43(24 \%)$ drank alcohol daily, and $38(21 \%)$ smoked cigarettes daily. In all five factors assessed the difference was significant $(P<0.001)$.

Table I shows the means and standard deviations for each factor of the questionnaire for the 181 patients in group 1 compared with the 'normal' population sample corrected to allow for a difference in sex incidence (Scheier and Cattell, 1961). The factors deviate significantly in the direction of tough-mindedness, depression, submissiveness, and high anxiety. The distribution of the scores on each factor was markedly skewed away from normal. When the patient's score on each factor was graded as low, average, or high, the tendency towards these poles was markedly accentuated (Table II).

Smoking, aspirin, and alcohol ingestion reported by each patient was examined separately in relation to each factor on the neuroticism scale questionnaire. No significant association was found between any factor and the degree of addiction to the three preparations, except when alcohol consumption was related to the dominant-submissive factor. Those who scored at the dominant pole more often acknowledged moderate or heavy alcohol ingestion than those at the submissive pole $\left(\chi^{2}=13.77, \mathrm{P}<0.01\right)$. Since only $17 \cdot 1 \%$ of the sample obtained scores of the dominant pole, this single significant finding is probably a false positive.

Each factor was related to the ingestion of all three preparations daily by a patient to determine whether an association exists between extreme scores and multiple 'drug' ingestion. A significant correlation emerged on the toughtender-minded factor (Table III) indicating that the significantly tough-minded patients do not report using significant quantities of aspirin, alcohol, and cigarettes. The tender-minded patients more often use all three of these while 


\begin{tabular}{|c|c|c|c|c|}
\hline \multirow[t]{2}{*}{ Factor $I$} & \multicolumn{4}{|c|}{$\begin{array}{l}\text { Significant Smoking, Aspirin, and } \\
\text { Alcohol Consumption }\end{array}$} \\
\hline & Nil & Any One & Any Two & Any Three \\
\hline $\begin{array}{l}\text { Tough-minded pole } \\
\text { (I-) } \\
\text { Average } \\
\text { Tender-minded pole } \\
(\mathrm{I}+\text { ) }\end{array}$ & $\begin{array}{cc}15 & (10 \cdot 1)^{1} \\
5 & (7 \cdot 9) \\
& \\
0 & (2 \cdot 1)\end{array}$ & $\begin{array}{l}21(25 \cdot 7) \\
25(20)\end{array}$ & $\begin{array}{l}34(37 \cdot 7) \\
25(26 \cdot 3)\end{array}$ & $\begin{array}{r}12(12 \cdot 6) \\
9(9 \cdot 8) \\
4 \quad(2 \cdot 6)\end{array}$ \\
\hline
\end{tabular}

Table III Observed relationship between 'drug' ingestion and between tough-mindedness and tendermindedness in patients with gastric ulcer

'Expected frequencies

\begin{tabular}{|c|c|c|c|}
\hline \multirow[t]{3}{*}{ Factor } & \multicolumn{3}{|c|}{ Gastric Ulcer Patients } \\
\hline & \multirow[t]{2}{*}{$\begin{array}{l}\text { Before } \\
\text { Treatment } \\
(1969)\end{array}$} & \multicolumn{2}{|c|}{ Follow-up } \\
\hline & & $\begin{array}{l}5 \text { to } 7 \\
\text { Years }\end{array}$ & $\begin{array}{l}15 \text { to } 17 \\
\text { Years }\end{array}$ \\
\hline I & 9.6 & 8.9 & $8 \cdot 6$ \\
\hline F & 11.6 & $11 \cdot 6$ & $11 \cdot 3$ \\
\hline E & $15 \cdot 3$ & $15 \cdot 1$ & 13.8 \\
\hline An & $13 \cdot 2$ & $12 \cdot 6$ & 11.8 \\
\hline
\end{tabular}

Table IV Mean scores for patients with gastric ulcer tested on admission compared with scores obtained at follow up

patients with average scores more often reported using one or two. This suggests that more extensive addiction to all three preparations is associated with tender-mindedness.

The presence of domestic and financial stress was related both to the personality dimensions and the smoking, aspirin, and alcohol consumption in each patient. No significant interaction between either stress and the personality variables was found. Of the patients 'addicted' to cigarettes, smoking, and/or alcohol, $37 \%$ noted domestic and/or financial stress compared with $39 \%$ for the 'non-addicted' patients.

Finally, the patients were divided into those admitted to hospital five to seven years and 15 to 17 years before completing the questionnaire. The factors were then compared with results obtained from a group of 20 patients with gastric ulcers admitted to the Queen Elizabeth Hospital in 1969, a neuroticism scale questionnaire having been completed before treatment (Table IV). There was no significant difference in any factor in the three groups.

\section{Discussion}

This group of patients with gastric ulcer demonstrates a pattern of personality traits which deviates from the normal population. The neuroticisim scale questionnaire (Scheier and Cattell, 1961) samples only four dimensions of personality and there may well be other psychological factors not assessed here in which gastric ulcer patients would deviate from the normal population. The conclusion from this test is that a high percentage of gastric ulcer patients are characterized by tough-mindedness and submissiveness. There are known sex differences in response to these scales but, when allowance was made for these, the pattern of deviation from normal is the same for male and female patients. Three dimensions have emerged which require interpretation: (1) the high anxiety factor $(\mathrm{An}+)$; (2) a combination of submissiveness $(E+)$ and of a marked tendency to develop depression $(\mathrm{F}+)$ -often labelled 'introversion'; and (3) toughmindedness (I-).

The pattern does not have the characteristics found among neurotic subjects (Kear-Colwell, 1965) but does correspond to a small group of 23 'psychosomatic' patients reported by Scheier and Cattell (1961). Our patients scored high on anxiety. This must be interpreted cautiously since high anxiety scores are almost invariably found in hospital populations (Robinson, 1964). Also, the presence of a depressive element might a priori be either causal or a consequence of the ulcer. If anxiety and depression were a result of gastric ulceration and hospitalization, we would have expected a return towards normality when comparison was made between responses from the patients questioned at admission in 1969 and those from the groups followed up after five and 15 years. It was also possible that the high scores were influenced by age, since the mean age of the patients was $61 \cdot 3$ years but no correlation with age was found.

It has been suggested by Cattell (1965) that psychosomatic patients are mistakenly described as neurotics and he emphasizes that 'effort-stress' is a key concept in these people. Scheier and Cattell (1961) defined this as 'a psychological and physiological response pattern, different from anxiety ... characterized by raised corticosteroid excretion and increased pulse rate.... It is sometimes produced by external demands and sometimes by high internal standards'. While this questionnaire does not allow a complete identification of 'effort-stress', the high rate of response to anxiety questions is consistent with this suggestion (Cattell, 1957).

Factor I- (tough-mindedness) represents a masculine, 'no-nonsense', self-sufficient individual. These traits arise from early childhood experience. This is in contrast to factor E+ (submissiveness) which describes a submissive, dependent person who is more feminine than masculine. This factor has a strong hereditary loading (Cattell, Blewett, and Beloff, 1955). There is, therefore, a conflict between the genetic and environmental influences in determining which sex role the patient will play. In describing the patient who scores at the submissive pole, Scheier and Cattell (1961) state that 'he may 
appear quite "considerate", kindly and softhearted, probably mainly because he fears and avoids the clashes which would result from assertive-hostile behaviour towards others. If there are unavoidable conflicts with others or any form of social disapproval, he is profoundly upset'. These features, together with the 'introversive' pattern already noted, support the evidence for the internalization of aggression which others have noted (Mirsky, 1958).

Since no difference between the sexes emerged in this pattern of scores, it is concluded that there is a conflict over a patient's genetic and environmentally induced sex role and the expression of hostile feelings, with both sexes tending to behave in a sex-inappropriate fashion while resisting this tendency. The importance of chronic conflict has previously been noted in the genesis of peptic ulcer (Brady, 1958), especially regarding sex-role conflict (Draper and Touraine, 1932). This may explain the increased incidence of marital disharmony found in patients with gastric ulcer (Gillies and Skyring, 1969; Alp and Grant, 1970).

It is difficult to determine whether this personality pattern and resultant conflict is causal or arises only following ulceration, since these patients were tested after having developed an ulcer. However, the dominant-submissive factor $\mathrm{E}$ is so strongly genetically predetermined that one may assume these patients were always high scorers (Cattell et al, 1955). The tough-minded, tender-minded dimension factor $I$ is predominantly affected by early home influences (Cattell et al, 1955). These also antedate the appearance of the ulcer. Also, the personality pattern of patients questioned at different intervals following ulceration is indistinguishable. Therefore, it can be assumed that the pattern indicates a preexisting personality type which is unaffected by the illness itself. In the absence of data of pre-ulceration, this type of sampling is an acceptable alternative approach to the issue of causality (Crisp, 1968).

No correlation has beenfound between personality characteristics, domestic and financial difficulties, and the intake of aspirin, alcohol, and cigarettes. This lack of correlation would suggest that the use of aspirin, alcohol, or cigarettes is not associated with a particular type of personality in dealing with stressful situations. However, it must be admitted that patients often tend to understate such 'addictive' habits, and also their problems, when questioned. In addition, we have only assessed two forms of external stress and there may be many other types of stress which are not externalized, or admitted, by the individual.

Therefore, since we have been unable to prove that a particular personality takes more 'aspirin and alcohol or smokes more cigarettes, or that these substances are used by patients under stressful circumstances, it is necessary to postulate several mechanisms which may lead to gastric ulceration. This may operate independently or by interaction and may be represented as follows:

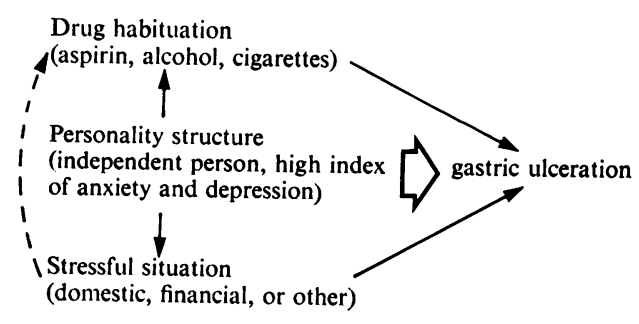

The evidence that stress situations are implicated in the causal sequence is well documented (Wolff, 1953; Weiner, Thaler, Reiser, and Mirsky, 1957).

We wish to express our appreciation to the honorary staffs and boards of the Queen Elizabeth and the Royal Adelaide Hospitals for permission to conduct this study, and to study case records of patients in these two hospitals. Mrs F. Low, of the University of Adelaide Computing Science Department, and Mr L. Veitch, of the CSIRO, Department of Computing Research, were very helpful in this survey. Great assistance was provided by Mr D. Aitchison of the Commonwealth Bureau of Census and Statistics, and the Registrar of Births and Deaths. Mrs E. Hackett and Mrs G. Bazeley assisted in the compiling of questionnaires. Mrs M. Davidson has typed the manuscript. We express our appreciation to the Queen Elizabeth Hospital Research Foundation for financial assistance in conducting this survey.

\section{References}

Alexander, F. (1950). Psychosomatic Medicine. Norton, New York.

Alp, M. H., and Grant, A. Kerr (1970). Gastric ulcer in South Australia. I. Epidemiological factors. Med. J. Aust., in the press.

Brady, J. V. (1958). Ulcers in 'executive' monkeys. Sci. Amer., 199, 95-100.

Brinton, W. (1859). The Diseases of the Stomach. Churchill, London.

Cattell, R. B. (1957). Personality and Motivation Structure and Measurement. World Book Co., New York.

Cattell, R. B. (1965). The Scientific Analysis of Personality. Penguin, Harmondsworth, Middlesex.

Cattell, R. B., Blewett, D. B., and Beloff, J. R. (1955). The inheritance of personality. A multiple variance analysis determination of approximate nature-nurture ratios for primary personality factors in Q-data. Amer. J. hum Genet., 7, 122-146.

Crisp, A. H. (1968). Some approaches to psychosomatic clinical research. Brit. J. med. Psychol., 41, 323-341.

Davies, D. T., and Wilson, A. T. M. (1937). Observations on the life history of chronic peptic ulcer. Lancet, 2, 1353-1360.

Draper, G., and Touraine, G. A. (1932). The man-environment unit and peptic ulcer. Arch. intern. Med., 49, 616-662.

Gillies, M. A., and Skyring, A. (1969). Gastric and duodenal ulcer: the association between aspirin ingestion, smoking, and family history of ulcer. Med. J. Aust., 2, 280-285. 
Personality pattern and emotional stress in the genesis of gastric ulcer

Højer-Pedersen, W. (1958). On the Significance of Psychic Factors in the Development of Peptic Ulcer. Munksgdard, Copenhagen.

Jones, F. A. (1957). Clinical and social problems of peptic ulcer. Brit. med. J., 1, 719-723.

Kear-Colwell, J. J. (1965). Studies of the IPAT neuroticisim scale questionnaire (N.S.Q.). Brit. J. soc. clin. Psychol., 4, 214-223.

Mirsky, I. A. (1958). Physiologic, psychologic and social determinants in the etiology of duodenal ulcer. Amer. J. dig. Dis., 3, 285-314.
Robinson, J. O. (1964). A possible effect of selection on the test scores of a group of hypertensives. J. psychosom. Res., 8, 239-243.

Scheier, R., and Cattell, R. B. (1961). Handbook for the Neuroticism Scale Questionnaire. Institute for Personality and Ability Testing, Champaign, Illinois.

Weiner, H., Thaler, M., Reiser, M. F., and Mirsky, I. A. (1957) Etiology of duodenal ulcer: I Relation of specific psychological characteristics to rate of gastric secretion (serum Pepsinogen). Psychosom. Med., 19, 1-10.

Wolff, H. G. (1953). Stress and Disease. Thomas, Springfield, Illinois.

\section{The August 1970 Issue}

\section{THE AUGUST 1970 ISSUE CONTAINS THE FOLLOWING PAPERS}

Immunoglobulins and dietary protein antibodies in childhood coeliac disease $\mathbf{K}$. G. KENRICK AND J. A. WALKER-SMITH

Sex hormones and acid gastric secretion induced with carbachol, histamine, and gastrin B. 0 . AMURE AND A. A. OMOLE

Immunofluorescence studies of the distribution of gastrin cells in different clinical states A. G. E. PEARSE AND G. BUSSOLATI

The endocrine polypeptide cells of the human stomach, duodenum, and jejunum A. G. E. PEARSE, I. COULLING, B. WEAVERS, AND S. FRIESEN

Investigation of gastroesophageal reflux in various positions with a two-lumen $p \mathrm{H}$ electrode $F$. G. PATTRICK

The transport of colonic contents in the irritable colon syndrome J. A. RITCHIE

Primary lymphoma of the upper small intestine KHOSROW NASR, PARVIZ HAGHIGHI, KIUMARS BAKHSHANDEH, AND MANSOUR HAGHSHENAS
The association between aneurysms of the abdominal aorta and peptic ulceration ALED W. JONES, R. S. KIRK, AND K. BLOOR

Recurrent perforation of the ileum J. D. CORMACK, M. A. MELSOM, AND J. G. WINWICK

Faecal stasis and diverticular disease in ulcerative colitis K. N. JALAN, R. J. WALKER, R. J. PRESCOTT, S. T. G. BUTTERWORTH, A. N. SMITH, AND W. SIRCUS

Failure of Trasylol to reduce intestinal content of trypsin and chymotrypsin in man $D$. $M$. GOLDBERG, R. CAMPBELL, AND A. D. ROY

The relationship between flow and electrolyte secretion in the canine pancreas A. N. FAWCETT

A study in vivo of adrenergic receptors in the rectum and in the internal anal sphincter of the cat R. KERREMANS AND F. PENNINCKX

\section{Progress report}

Gastric ulcer and regurgitation gastritis JOHN P. DELANEY, JOHN W. B. CHENG, BROOKS A. BUTLER, AND WALLACE P. RITCHIE JR

\section{Progress report}

Intestinal peptidases T. J. PETERS

Notes and activities

Copies are still available and may be obtained from the PUBLISHING MANAGER, BRITISH MFDICAL ASSOCIATION, TAVISTOCK SQUARE, WClH 9JR price 17s. 6D. 